\title{
Sociocultural Factors As Determinants of Female Entrepreneurs' Business Strategies
}

\section{Introduction}

Entrepreneurs are both constrained and enabled by the institutions in their environment has been widely acknowledged in the literature (Bruton and Ahlstrom 2003; Scott 2007). The institutional context draws on the concept of formal and informal institutions as "rules of the game" (North, 1990). Formal institutions are political and economy-related rules which create or restrict opportunity fields for entrepreneurship such as laws and regulations for market entry and exit. Informal institutions include the norms and attitudes of a society such as the value society generally puts on entrepreneurship or the roles of women in society that might restrict the nature and extent of their entrepreneurial activities. The institutional context constrains the range of strategic options (Ahlstrom and Bruton, 2002) for nascent entrepreneurs and helps to determine the process of gaining legitimacy, which is critical for entrepreneurs to overcome the liabilities of newness, (Stinchcombe, 2000) and to increase survival prospects (Ahlstrom and Bruton, 2002).

The application of institutional theory has proven itself to play a major role in helping to explain the forces that shape entrepreneurial success (Bruton and Ahlstrom 2003; Bruton et al., 2010). The three-dimensional model of country institutional profiles of entrepreneurship (Busenitz, et al., 2000) responds to the need for using a common conceptual framework in identifying differences among entrepreneurs from different cultures (Hayton, et al., 2002). The model includes the regulatory, cognitive, and normative aspects of a culture that are expected to influence levels of entrepreneurship within the culture and also across cultures. Cognitive institutions represent models of individual behaviour based on subjectively constructed rules and meanings that limit appropriate beliefs and action (Scott 2007; DiMaggio and Powell, 1991) whilst normative institutions exert influence because of a social obligation to comply, rooted in social necessity or what an individual should be doing (March and Olsen, 1989) Regulative institutions stem primarily from governmental legislation and industrial agreements and standards (Bruton et al., 2010).

Institutional theory is widely accepted as a suitable frame of reference for addressing the external context that shapes women's entrepreneurial activity, especially when cultural conditions create additional barriers for women. This is particularly true when considering that women are still defined primarily through their domestic roles and family obligations within many societies (Achtenhagen and Welter 2007; Marlow 2002). A framework drawing on institutional theory aims to close the gender gap in academic research (Brush et al., 2009). This gender-aware framework, that is referred to as the " $5 \mathrm{Ms}$ " is built on an existing $3 \mathrm{Ms}$ framework that is organised around three fundamental building blocks of business viability, namely market, money and management (Bates, et al., 2007). An entrepreneur needs to have access to markets (Schumpeter, 1934; Kirzner, 1985; Shane, 2003), money (Penrose, 1959; Bruno and Tyebjee, 1982) and management (Aldrich, 1999) in order to launch a venture. And yet, the $5 \mathrm{Ms}$ framework extends the scope of the $3 \mathrm{Ms}$ through the inclusion of further dimensions, namely "motherhood" and the "meso" and "macro" environment, to take into account any uniqueness of women's entrepreneurship (Brush et al. 2009, p.9). The 5Ms framework is rooted in the premise that entrepreneurship is socially embedded (Davidsson, 2003) and therefore it draws on institutional theory (Allen, et al., 2010). Both motherhood and the meso-macro environment mediate the entrepreneurial activity of women in different ways. Another application draws on institutional theory is called The Quality Assessment of Entrepreneurship Indicators which identifies six critical institutional factors affecting entrepreneurship, these 
being: regulatory frameworks; creation and diffusion of knowledge; market conditions; entrepreneurial capabilities; access to finance; and entrepreneurship culture (OECD, 2018).

Many studies employing institutional theory have examined culture, as a variable able to influence individuals' motivations, values and beliefs, and through them the entrepreneurial potential (Brancu et al., 2015), and its impact on entrepreneurship through utilizing institutional theory (Bruton et al., 2010). It is widely accepted that institutional forces reflect and reinforce cultural values (Hayton et al., 2002) and entrepreneurial activity is embedded in social and cultural norms and values (Krueger et al., 2013) results in the entrepreneur is being a product of their economic, institutional and cultural environment (Yetim 2008; Bruton et al., 2010). Culture, therefore, influences the supportiveness of the environment so as to make it more legitimate to form a new business (Etzioni 1987; Hayton et al., 2002) and constrain the range of strategic options (Ahlstrom and Bruton, 2002) for nascent entrepreneurs. Entrepreneurs develop unique business survival and growth strategies (Terjesen and Lloyd, 2015) whilst social institutions provide them with access to the necessary resources (Abzari and Safari, 2014) for entrepreneurship to emerge within a culture.

Undoubtedly the most popular measures of countries' normative environment depend on Hofstede's (1980) dimensions of culture. Hofstede's work presents a concise taxonomy of significant cultural dimensions for explaining the behavioural preferences of entrepreneurs. Especially the definitions of the dimensions and their expected associations with levels of entrepreneurship are extensively covered by previous research (Hayton et al., 2002) that has produced conflicting results (Freytag and Thurik, 2007) and views as summarised in Table 1. Hayton and Cacciotti (2013) assert that due to the fact that the influence of sociocultural factors on entrepreneurship remains under-studied, the culture-entrepreneurship literature is messy.

\section{$<$ Table 1 is here>}

Although previous research has developed strong insights into the similarities of entrepreneurs across cultures, to date limited studies have examined the country-specific sociocultural factors which may account for variance in women entrepreneurs' business survival strategies (Kaciak and Welsh, 2018, p.631). This study attempts to close this gap through taking a closer look at the country-specific sociocultural factors creating differences in female entrepreneurs' entrepreneurial behaviour and business strategies in multiple countries for wider applicability (Bruton et al., 2010). In light of previous studies examining the impact of social institutions, this paper examines whether networking strategies, growth orientation, perceived impediments at startup, working hours, business industry choices and partnership structures, of wellestablished female entrepreneurs vary between two different cultural environments, namely the UK and Turkey. From the institutional theory perspective it is expected that, since entrepreneurial strategies are strongly linked with and shaped by culture, the two countries' female entrepreneurs should exhibit fundamentally different patterns with regards to these factors due to their fundamentally different socio-cultural environments (Table 2 and 3 ). If not, then we might question whether the cultural environment has a significant impact upon the development of entrepreneurial behavioural patterns.

Therefore, this paper aims to present the findings from quantitative survey-based research conducted with 240 female entrepreneurs from the UK and Turkey (120 from each). The respondents were selected on the basis of business survival where the majority of businesses were older than five years. To describe the cultural environments chosen, the Hofstede Model of National Culture is used. Although the model has six dimensions, the long-term orientation and indulgence dimensions were not applied to the case countries due to Turkey's intermediate scores indicating no dominant cultural preference (Hofstede, 2018). 
Based on the Model, the culture profiles of the UK and Turkey are given in Figures 1 and 2, and further detailed in Table 2 and 3 below.

\author{
$<$ Figure 1 is here> \\ $<$ Figure 2 is here> \\ $<$ Table 2 is here> \\ $<$ Table 3 is here>
}

This paper is organised as follows. The next section provides an overview of the socio-cultural environments surrounding women in the two case countries, alongside further consideration of the literature concerned with the relationship between female entrepreneurship and culture. This directly precedes the methodology which is in turn followed by the presentation of survey findings and a discussion of the key themes observed. Some concluding remarks are then drawn.

\title{
2. Women's Status
}

Women's status in society is one of the most controversial topics in Turkey. The gap between women's status and rights that the law provides and protects and their reality in practice is substantial, and the government has not addressed this gap through policy development. Although gender equality is protected by the Constitution, the government has been strengthening the patriarchal values in the society and challenging to this provision through reintroducing women as a domestic worker and a mother who need to stay away from the labour market. The contradictory actions of the government regarding its women-related policies and its efforts to promote female entrepreneurship are claimed to force women into informal entrepreneurship (Nazliaka 2017; Yetim 2008).

On the UK side, the so-called 'gender role revolution' is at the doorstep (Esping-Andersen, 2010). There has been a rise in women's participation in the labour market over the past few decades and, in today's couple families, the tendency is for both partners to work. With this rise in labour market participation, policy-makers have taken steps to reduce family-work conflicts, including through childcare provision, improvement in part-time working conditions and parental leave (Williams, 2005). However, women, especially those with young children, still disproportionately work part-time and continue to perform the bulk of unpaid care (Scott and Clery, 2013).

Turkish men, in contrast, take no childcare responsibilities and instead leave it to the rest of the household, with further differences in paternity leave conditions between the two countries reinforcing this (Dad, 2019). Against this backdrop, motherhood is the main career of women with young children in $86 \%$ of cases (Turkstat, 2018). Women also generally undertake all household chores. British women undertake $60 \%$ of housework and $70 \%$ of caring for family members. In total, a British woman spends an average of 36 hours on domestic responsibilities as compared to the 18 hours recorded by men (Scott and Clery, 2013).

The female labour force participation rates are $72 \%$ and $36 \%$ in the UK and Turkey respectively. Prominently, 58\% of employed women in Turkey work in the service industry and $26 \%$ in agriculture (Turkstat, 2018). The most common sector of employment for women in the UK is health and social work (The World Bank, 2018), with 78\% of jobs in this sector and $70 \%$ of jobs in education being held by women. Similarly to Turkey, sectors where only a small proportion of jobs are held by women include construction (14\%), transportation and storage (22\%) and manufacturing (24\%) (McGuinness, 2018). 
Around $11 \%$ of women are self-employed compared to $19 \%$ of men in the UK (McGuinness, 2018). The self-employment rates of males and females in Turkey are $36.6 \%$ and $31 \%$ respectively. However, these figures do not provide an accurate picture of the gender-based employment pattern in Turkey. Income generation through commercial activities is forbidden by law for full-time employers in the country. Therefore, males employed full-time tend to setup a business under their wives' names without the wife's consent and knowledge (Kizilkoyun, 2012).

The literacy rates are $99 \%$ and $92.65 \%$ in the UK and Turkey respectively (Country Economy, 2018). The rate of illiterate women remains five times more than that of males in Turkey (Turkstat, 2018). This gap partly closes in the higher education category where $13.1 \%$ of females compared to $17.9 \%$ of males participate. Turkish women cannot complete their education mostly for the reasons of the family's not allowing, economic reasons and getting married/engaged/becoming mother/being pregnant (Turkstat, 2018). The higher education participation rates are $56 \%$ and $44 \%$ for females and males in the UK respectively (GOV, 2018).

Violence against women in Turkey is another fundamental problem. In 2017, 409 women were killed by their relatives for various reasons, including requests for more freedom in life (The Guardian, 2017). Domestic violence against women in the UK also remains a serious problem. For instance, a British Crime Survey demonstrated that $45 \%$ of women had experienced at least one incident of domestic violence or sexual assault since the age of 16 (BL, 2013). Table 4 and Figure 3 shows a comparison between Turkey and the UK on various entrepreneurship and economic indexes.

\section{$<$ Table 4 is here> \\ <Figure 3 is here>}

Turkish female entrepreneurs, especially those living in rural areas, are deprived from any kind of structured and accessible support from women entrepreneurship support organisations. KAGIDER (Women Entrepreneurs Association of Turkey) is the most influential and powerful women entrepreneur organisation in the country, boasting three branches situated only in two big cities in Turkey and Brussels. In contrast, there are countless accessible regional and national women entrepreneur support organisations in the UK, with female entrepreneurship further supported by the Chamber of Commerce, even in smaller towns.

\section{Female Entrepreneurship from the Institutional Perspective}

Women entrepreneurs around the world face both social and structural challenges (Welsh et al., 2016). The social challenges include a lack of self-confidence, facing dominant patriarchal mindsets and institutionalised sexism, bearing the responsibility for the household and childcare, and receiving only one chance at being in business due to the lack of familial and societal support (Moghadam, 2003).

Structurally, the first challenge is a lack of education and knowledge in the areas of skill development, basic business and women's rights (Welsh et al., 2016). Second, there exists legal discrimination and a lack of economic and political power for women. As such, when women attempt to launch a business they confront a number of barriers, including around access to finance, lack of customer confidence and respect, sexual harassment, lack of community respect and wage differentials (Hisrich and Brush 1988; Lee-Gosselin and Grise 1990; Hatun and Ozgen 2001). There can additionally be limited governmental support for women entrepreneurs, especially in developing countries (Welsh et al., 2016). 
To begin, Turkish female entrepreneurs have been caracterised as being commonly involved in the service sector, more willing to take risks and often found to be in a disadvantageous position regarding financial network ties when compared to their British counterparts (Terjesen and Lloyd, 2015). The major problems that Turkish female entrepreneurs encounter are identified as including finance, balancing of family and work life, discrimination (Simsek and Uzay, 2009), personnel problems, lack of business mentorship or networking opportunities, limited business experience (Nazliaka, 2017) and similarly low hiring experience (Hisrich and Ozturk, 1999). The government has also been discussed as a major obstacle to their success due to policies regarding production and financial issues, extending from complicated tax laws to gaps in social policy concerning the work-family balance that are not being addressed; the latter relating to childcare and elder care (Welsh et al., 2016). While being an entrepreneur affects Turkish female's roles in family life negatively due to a "clash of commitments" (Welsh et al., 2016), it can have a positive effect on their roles socially, economically and individually (Hatun and Ozgen, 2001). Beyond suffering from stress associated with insufficient demand for their products or services, Turkish female entrepreneurs further believe that entrepreneurship is stereotyped as a masculine profession and therefore will not be immune to gender-based bias (Carter and Williams 2003; Welsh et al., 2016). Kutanis and Bayraktaroglu (2003) discovered that one third of Turkish women entrepreneurs are dependent entrepreneurs who maintain a business that was already established by either a father, brother(s), or husband. Those male members of the business were in turn found to become business mentors for the female members. Family and their moral support play an important role in Turkish women's personal and professional lives. Family moral support empowers family members to influence work and can help the female entrepreneur recognise and address her weaknesses through open communication. In this context, Powell and Eddleston (2013) show that female entrepreneurs experience benefits from both instrumental and affective family enrichment and support (Welsh et al. 2016; Kaciak and Welsh 2018). Contrarily, the same support can create conflict and exacerbate women entrepreneurs' problems due to family members' authority, legitimacy and power to interfere with the business (Welsh et al., 2016). Shelton (2006) therefore suggests that work-family conflict may impact venture performance negatively due to the spillover of negative emotions, attitudes and behaviours from family to business relations (Jennings and McDougald, 2007).

Turning to the other case, public support for a traditional division of gender roles within the home and the workplace has declined substantially recently, a change that goes hand in hand with the marked increase in the labour force participation of women and mothers. On the other hand, gender equality in terms of who is primarily responsible for domestic chores has made very little progress (Phillips, et al., 2013). Terjesen and Lloyd (2015) assert that female entrepreneurs in the UK are largely involved in technology sector businesses, are well-educated and enjoy a wide range of accessible support and training programmes across the country. The social challenges that the British female entrepreneur encounters prominently includes a lack of self-belief and the fear of failure. The structural challenges are, first, a self-perceived lack of key business skills, especially in the areas of financial management and market development. Second, limited access to role models, business mentors and related networks (Deloitte, 2016). Fernandes (2018) concludes that the major problems that British female entrepreneurs encounter are identified as limited access to funding, social expectations to act as a male, the threat of not being taken seriously, difficulties in building a robust network with professionals, establishing a healthy family-work balance and the fear of failure. Related to these factors, it should also be noted that the literature further observes how female business networks are generally smaller in Turkey as compared to those in the UK (Welsh et al., 2016). Both British and Turkish female entrepreneurs suffer from invisibility in business (Mueller and Thomas, 
2001) and, similarly to their Turkish counterparts, female entrepreneurs in the UK think that an entrepreneurial career holds a high status in society (GEM, 2017).

The male/female self-employment ratios are 10 and 2.6 in Turkey and in the UK respectively (OECD, 2017). OECD Economic Surveys Report (2018) asserts that, the factors discouraging women from any form of formal employment (such as low gender egalitarianism) are initially rooted in cultural patterns. And yet, economic necessities, the lack of access to productive resources (Vossenberg 2013; Overå 2016), the unfavourable government policies and maledominated finance industry (Karlan, et al., 2015) push women into informal entrepreneurship albeit women take advantage of the more flexible work arrangements within the informal economy. Studies posit that the rationale behind women disappearing from the labour statistics particularly in developing countries is their increasing engagement in informal employment (Dedeoglu, 2008). Turkey is in fourth place in terms of the size of the informal economy among the OECD countries. About $42 \%$ of women who work in Turkey do so informally (ILO, 2018), $98 \%$ of which do not have access to social security and their economic activities are not regulated (Turkstat, 2018). Among women in any form of employment, only 5\% are in the formal economy (ILO, 2018). Turning to the other case, $10.9 \%$ of women in any form of employment work informally (ILO, 2018). 56.4\% and $0 \%$ of women in the informal economy are contributing family workers in Turkey and in the UK respectively. $16.3 \%$ and $1.2 \%$ of women in the informal economy are self-employed in Turkey and in the UK respectively (ILO, 2018). From the institutional theory perspective, the tendency for entrepreneurs to operate informally is explained as resulting from the asymmetry between the formal and informal institutions within a society; the greater the incongruence between formal and informal institutions, the more entrepreneurs operate in the informal sector (Williams and Shahid, 2016).

\section{Methodology}

The data were collected through a survey study. A survey was deemed to be the most appropriate method for the purpose of this study for three reasons: first, survey research is used to quantitatively describe specific aspects of a given population; second, the data required for survey research are collected from people and are, therefore, subjective; and, finally, survey research uses a selected portion of the population, with findings able to be generalised back to this population as a whole. The survey design process was completed in two steps: developing the sampling plan and creating the survey questions (Glasow, 2005). The data were transferred onto Excel and SPSS for further analysis.

As noted above, to describe the cultural environment within Turkey and the UK, Hofstede's Model of National Culture was used (Hofstede, 2018). Turkey is a country characterised by high power distance, high uncertainty avoidance, femininity and collectivism. The UK, on the other hand, is a country of individualism, masculinity, low power distance and low uncertainty avoidance. These two countries are, therefore, appropriate choices for comparing the successful business strategies of established female entrepreneurs in two fundamentally different cultural environments.

\subsection{Sampling}

The target sample group was comprised of successful female businesses within northwest England and western Turkey. These regions were selected due to their convenience and accessibility. On the UK side, the sample group was accessed through women business support organisations (such as the Liverpool Ladies Network), the University of Liverpool's Lead

Innovative Leadership Programme, Manchester University's Innospace Programme and Chamber of Commerce organisations. On the Turkish side, women were accessed through Chamber of Commerce organisations and Çanakkale Onsekiz Mart University business 
network. The survey was also applied through face-to-face interviews at various business events.

After collecting the responses, the final sample selection was made on the basis of business success. Only successful businesses or, in other words, established entrepreneurs were accepted to this study. The business success criteria were: age of business ( $>5$ years); stability or growth recorded on profitability; sales volume; and number of employees within the last financial year. In total, 240 females participated in this study with 120 from each country.

\subsection{Question Wording}

Two existing surveys were used to create the questions: the FSB survey, Lifting Barriers to Growth in UK Small Businesses by University of Glamorgan Business School (Carter et al., 2006) and The NES Follow-Up Survey (Jayawarna et al., 2006) which had been used and tested by the National Federation of Self Employed and Small Businesses Limited and Manchester University respectively. The survey was translated into Turkish for the Turkish participants and was initially tested with 30 respondents (15 from each country) to eliminate any misinterpretation or potentially offensive statements. The final survey was transferred onto Survey Monkey and distributed with great help from the aforementioned organisations across the case regions.

\subsection{Reliability Analysis}

Cronbach's alpha is the most common measure of the internal consistency (reliability) of a questionnaire. The reliability test results for this study are shown in Table 5 and indicate a high level of internal consistency for the questionnaire.

$<$ Table 5 is here>

\section{Findings}

\subsection{Demographics and Educational Achievement}

In respect of demographic features, the majority of participants from both groups were within the ages of 31 to 40 and married with children. The British participants held postgraduate degrees and studied art. The Turkish participants held undergraduate degrees and studied business or social science more broadly. Based on their latest subject of study, it can be asserted that the British participants decided upon a more specific, industry-dependent subject, namely art, whilst their Turkish counterparts preferred to stay on the safe side through studying quite a generic and industry-independent subject, namely business. Half of the British businesses were linked to the arts in some way, therefore speaking directly to their latest subject of study. On this point, a study posits that $28 \%$ of British women have turned their hobby into a business (Ferguson, 2017) with the aim of achieving a greater job satisfaction (The Guardian, 2017). $33 \%$ of the Turkish participants in the study at hand stated that their businesses were not linked to their subjects of study at university. It is notable that the British participants had a higher level of academic achievement than their Turkish counterparts which, it will be argued, can be related to cultural differences. To elaborate briefly, the majority of Turkish women do not pursue their education further mostly because the family will not allow it, such as for economic reasons, or due to changes in familial circumstances, including through marriage or motherhood. The average (mean) age at first marriage for women in Turkey is 23.3 years, which coincides with the end of university education (Turkstat, 2018). The average age at first marriage for a woman in the UK is 35.1 years (BBC, 2018).

It is evident in the further training participation rates that formal academic education was not enough to succeed in business for our participants. Regardless of their educational level, the majority of participants had engaged in further entrepreneurship-related training (72\% of 
Turkish and $89 \%$ of British participants) to improve skills, confidence and knowledge. As before, the subject preferences vary between the two groups. The British participants were observed to have undertaken training on leadership, management and operational issues, whilst the Turkish respondents largely undertook training around sectoral information, English language skills and leadership.

\subsection{Previous Employment and Entrepreneurial Experience}

Among the British participants, the oldest surviving businesses (older than 10 years) had been founded within the ages of 20 to 29 . The second oldest surviving businesses (6 to 10 years old) had been founded within the similar age range of 21 to 30. The third group of businesses (4 to 5 years old) had been established within the ages of 26 to 35 . On the Turkish side, the oldest surviving businesses (older than 10 years) had been established between the ages of 30 and 39 . Businesses aged 6 to 10 and 4 to 5 years had been founded within the ages of 31 to 40 and 26 to 35 respectively. Therefore, British participants had established their first - and successful businesses at a younger age than the Turkish group. In almost every business age category, the Turkish entrepreneur was older than her British counterpart.

The majority of participants were in non-managerial employment in a different industry than their existing business (37\% and 29\% British and Turkish respectively) with a minority in selfemployment (12\% and 23\% British and Turkish respectively) prior to setting up their current businesses, thereby demonstrating that a small percentage of participants did hold a previous entrepreneurial experience. The second business ownership rate among the Turkish cohort is two-fold of the British one. The rates of business closure and handover among the Turkish group outnumbered the rates of the British sample by 3:1 and 11:1 respectively. Only the soldout rate is higher among the British participants.

Both groups had started their current businesses from scratch. The British females held sole ownership over the business $(73 \%)$ as opposed to the Turkish females who often held joint ownership with close relatives and/or husbands $(72 \%)$. Further relating to familial ties, the majority of Turkish respondents $(63 \%)$ had an entrepreneur family member as opposed to the British participants who commonly had none $(76 \%)$.

\subsection{Growth Orientation}

The British participants exhibited strong growth orientation with $83 \%$ wanting to grow their businesses. The growth-oriented participants identified a number of impediments against such growth, however. The major impediment specified was the existence of uncertainty and increasing competition in the market (48\%) followed by the absence of suitable and accessible external funding (17\%), skilled staff (16\%) and affordable physical resources such as building premises $(9 \%)$. In order to test the significance of the relationship between growth orientation and the perceived impediments towards growth, the Chi Square $\left(\chi_{2}\right)$ test ran. The results showed that all the stated obstacles above were significantly linked to growth orientation.

$17 \%$ did not want to grow their businesses because they wanted to maintain a healthy balance between work and life (50\%) and they wanted to keep their business at a manageable size so that they could retain full control over it (41\%). Only $9 \%$ did not want to grow with no specific reason. The $\chi_{2}$ test results showed that there was a significant relationship between the intention not to grow the business and considerations regarding work-life balance and the overall manageability of the business.

The Turkish participants were also growth-oriented with 93\% intending to grow their businesses. The major impediments against business growth in this context were uncertainty and intense competition in the market (35\%) followed by the limited availability of suitable external funding (22\%), as well as a lack of skilled staff $(22 \%)$, legal requirements $(8 \%)$ and 
an absence of affordable physical resources $(6 \%)$. The $\chi^{2}$ test results showed that the obstacles of uncertainty and intense competition in the market, lack of suitable funding and lack of skilled staff were significantly related to growth orientation among this sample's growth-oriented females.

Similar to the UK results, $7 \%$ did not want to grow their businesses on the Turkish side. They did not wish to do so predominantly because they wanted to keep the business at a manageable size $(61 \%)$ and they cared about having a healthy work-life balance $(30 \%)$ which would have been affected negatively with business growth. $9 \%$ stated that they did not want to grow due to unfavourable market conditions. Among the reasons not to grow, unfavourable market conditions is the sole variable that held a significant relationship with the lack of growth orientation. Keeping a healthy work-life balance and keeping the business within a manageable size were the main priorities and were subsequently more important than entrepreneurial growth for the British and Turkish participants respectively.

\subsection{Obstacles At Startup}

The British participants were more concerned about their individual capabilities and sufficiency than any external barriers as impediments at startup. The participants reported that they were not fully confident about setting up a business (53\%) due to lack of skills and confidence, insufficient time to devote to the business and concerns about the potential impact upon work-life balance. The other obstacles at startup were social networking (26\%), finance (12\%) and gender-based discrimination-related (3\%) issues. Only 4\% of respondents claimed that they did not encounter any obstacles when establishing their business.

On the Turkish side, social networking related obstacles (including a lack of family support, accessible mentorship or accessibility to other entrepreneurs) had the strongest negative impact at startup (28\%) followed by individual-based obstacles such as limited skills and training $(26 \%)$. Funding related barriers $(15 \%)$ and gender-based discrimination $(10 \%)$ were among the other impediments encountered at startup. Only 5\% reported experiencing no obstacles. In summary, therefore, the top three impediments encountered at this stage were managing worklife balance, fear of failure and networking for the British participants, and limited startup capital, no indication of an obstacle and maintaining work-life balance among the Turkish group.

\subsection{Networking}

Networking pattern analysis was conducted based on four elements of the networks: type of contact; networking motivation; frequency of contact; and helpfulness of contact.

The British participants' two predominant networking motivations were obtaining moral support and gaining business referrals from close relatives, friends, customers and suppliers. Evidently, these contact groups were consulted often and found to be very helpful by the participants. As such, the participants placed their relatives, friends and key stakeholders within their closest network layer. The other contacts from which moral support was sought were specified as previous work colleagues, other female entrepreneurs and women-related organisations. The participants were further engaging with trade associations to gather industry related information, in addition to professional services and the Government to access business advisory services. They identified "Universities" as a source of skills development opportunities, but had never contacted a university for this purpose. Aside from their closest contacts, these other network interactions were also found, at least in some limited capacity, to be helpful by the participants.

As for the Turkish entrepreneurs, their networking pattern demonstrated numerous differences. For instance, they were keeping their relatives and friends closest to themselves and contacted 
them very often to obtain moral support, whilst the key stakeholders were contacted fairly often to obtain business referrals. On frequency, it was observed that the Turkish participants were not as close to their key stakeholders as the British were, which stemmed from the fact that "dealing with externals - regardless of their key stakeholder status" was considered the male business partner's responsibility. Aside from family and friends, other female entrepreneurs, women-related organisations and previous work colleagues were sources of moral support. It was striking that they were taking part in government projects to obtain moral support as well given these projects are an unusual means by which to obtain such support. Trade associations, universities and government were specified as the main source of industry information. Different than the British participants, the Turkish respondents had maintained a relationship with universities on an occasional basis to obtain skills improvement opportunities. The Turkish participants had six different contact groups in their networks which were contacted frequently ("very often" and "fairly often") as opposed to three for the British participants.

\subsection{Working Hours}

The majority of British participants (56\%) were working more than 40 hours per week. Of these, $22 \%$ stated spending a minimum of 50 and maximum of 59 hours on the business. Similarly, the majority of the Turkish participants (73\%) also claimed they were working more than 40 hours per week. The mean values of each group indicated that the British respondents spent more time at work than their Turkish counterparts, standing at 41 and 34 hours respectively. To test the significance of the relationships between weekly working hours, business partnership status, entrepreneurs' age and marital status, the Kruskal-Wallis test ran. The test did not generate any significant relationships between the variables.

\subsection{Business Industry and Business Survival}

The majority of the both groups had preferred to establish a business in the service sector, which is generally characterised more as a female industry (Sweida and Alan, 2015). The rate of manufacturing businesses among the Turkish participants was around 15 times higher than that of the British participants.

All research participants were established female entrepreneurs. To identify the variables which had an impact on business survival, the Chi Square $\left(\chi^{2}\right)$ test ran between them. These results are shown in Tables 6 and considered in greater depth within the following discussion. Table 7 shows a representative result of the $\chi_{2}$ test.

\section{$<$ Table 6 is here> \\ $<$ Table 7 is here>}

\section{Discussion and Conclusion}

Within the context of this study, the established entrepreneur was defined as someone who had found success in her business that was at least five years old at the time this study was conducted. The findings showed that the established British female entrepreneur is more educated than her Turkish counterpart. Based on the power distance index scores, this result is not surprising since in high power distance cultures such as Turkey, women's access to education is restricted and they do not progress further with their education mostly because the family will not allow it, or due to getting married or becoming a mother. As noted previously, the average Turkish woman gets married in her 20s, which coincides with the end of university education, and subsequently adopts the priorities of settling into the marriage, having children and raising them to a less dependent age before starting an entrepreneurial career.

The Turkish woman studies either business or any other subject within the social sciences to increase her chances of finding a job in any industry. Yet, conversely, the British woman 
follows her passion and studies art. The subject preferences of both groups of females is arguably linked to the individualism aspect of their culture.

Regardless of their higher educational achievements, the British woman still feels insufficient to pursue an entrepreneurial career and participates in further entrepreneurial training, such as around leadership, managing an organisation or understanding sectoral characteristics. When considering the majority studied art, this effort is highly logical. And yet, the Turkish female also seeks opportunities to improve entrepreneurial skills and English language ability. The findings show that Turkish women might have stopped their education with marriage, but they continue with work until they become involved in business similarly to their British counterparts.

The collectivism cultural dimension stands out as one of the determinants of business partnership status, with this status showing a meaningful difference between the two groups. The Turkish female has relatives as business partners whilst the British female is a sole trader. From the western perspective, collective action in business might be perceived as an impediment towards independence, autonomy and scope of control (Huffingtonpost, 2014). Furthermore, collective action in the form of business partnerships might be perceived as a foundation from which conflicts can emerge. However, the way in which collectivism was reflected in Turkish females' businesses indicated that this cultural dimension can be utilised as an enabler instead. First, collective action through business partnerships with their closest relatives enables female entrepreneurs to spend less time on work than those who do it alone. This enables women to become more flexible in splitting their time between work and any domestic responsibilities they may have. Also, being surrounded by relatives enables those females to get help with domestic work and receive moral support immediately when needed. It does still seem that collective action in business carries a serious risk of conflicts emerging between the partner relatives, as might quickly affect the relationships negatively and potentially create a butterfly effect with regards to extended family. However, in this study none of the Turkish participants reported conflicts with their partners as an impediment. Contrarily, having close relatives within the business itself and in the business network in general seemed to be a necessity rather than something to avoid especially when considering that unfavourable government policies prevent women from obtaining financial assistance from the male-dominated finance sector. Turkish female entrepreneurs turn to their business partners and social networks to survive their entrepreneurial attempts in this respect. Also, dealing with the government and other externals was reported as constituting part of the male partners' business activities which explains the low level of perceived gender-based discrimination with regards to external funding. Second, collective action in business enables female entrepreneurship to be legitimised and accepted by wider society. Based on the networking related findings, it is observed that Turkish participants primarily look after internal business functions and leave external functions to the male relatives as business partners. This reduces their stress since they do not need to deal with the bureaucratical processes involved in using external funding or managing relationships with government agencies. Consequently, although she is an established entrepreneur, the Turkish female still stays within her domestic environment which consists of her family members and friends. Third, women can take part in entrepreneurial activities and get a certain level of satisfaction without committing themselves to the business fully. The Turkish female entrepreneur is enabled to contribute to the business on a casual basis while raising children and fulfilling other domestic responsibilities. The relatives, as business partners, help and support her on the both sides, i.e. in business and domestic life. Therefore, the Turkish female entrepreneur has a unique opportunity to learn and prepare herself for a greater commitment to the business. Finally, having relatives as business partners facilitates the maintenance of trust relatively easier than can be the case with strangers. 
Having known each other for longer enables the female entrepreneur to evaluate the credibility and reliability of the relative as a (potential) business partner. Therefore, relatives' involvement in business reduces the risk and uncertainty around human relationships and trust. Relatives are selected on the basis of their closeness to the family and the business contacts they can utilise for the purpose of growth. It is important that entrepreneurial firms legitimize their activities if they are to secure resources and support from stakeholders and society (Bruton \& Ahlstrom, 2003).

Although growth-orientation was evident in the number of females intending to grow their businesses, they were not determined and fully driven towards growth due to a range of perceived barriers. Both groups specified the strongest impediments towards business growth as uncertainty and competition in the market, as well as the lack of qualified staff available. When it comes to their priorities, work-life balance was more important than business growth for the British participants. The Turkish participants also demonstrated a desire to maintain a work-life balance, but keeping the business at a manageable size was more important than business growth and work-life balance overall. This might be rationalised against the lack of qualified relatives suitable for the business and the reluctance to recruit professionals in their place. As a result, a significant difference in growth orientation between the participant groups was not observed.

On the other hand, there was a significant difference in weekly working hours. The mean value of the total hours spent at work showed that the British participants spend seven more hours working than the Turkish respondents. This might seem contradictory to the British participants' strong desire to maintain a balance between work and life. Since the Turkish entrepreneur has relatives around her as business partners rather than holding sole ownership, she has a foundation more conducive to flexible working patterns and a greater manageability of work and life.

As for the perceived obstacles at the startup phase, the British females specified more individual-based barriers compared to the Turkish participants, who reported more social capital based barriers at startup. The individual-based barriers evolved around a perceived insufficiency in skills and capabilities, lifestyle preferences and priorities, and a lack of selfconfidence. The social capital-related barriers at startup revolved around not getting enough support from external contacts and limited accessibility to necessary resources such as training, mentorship and business advisory services. From the institutional theory perspective the British females, as nascent and solo entrepreneurs, might have perceived some potential challenges towards complying with the institutional forces surrounding them especially when considering that they traditionally lack self-belief and encounter limited access to role models, business mentors and related networks as previously explained. And yet, the Turkish females were always surrounded by their closest male relatives as business mentors and facilitators of gaining legitimacy by the society through collective action in business. The collective action serves as an acknowledgement of females' entrepreneurial attempts by the extended family which facilitates social legitimisation.

The Turkish participants reported four-fold more gender-related barriers than the British participants. Related to this high power distance culture, Turkish females also specified more barriers towards accessing training and skills development opportunities, or business advisory services which were not catered for their special needs and circumstances. The Turkish participants reported three-fold more barriers related to government regulations. However, it was stated by the Turkish females that they overcome these barriers through their male business partners. When they are restricted and even prevented from accessing a particular resource on the grounds of gender, they are replaced with a male partner to obtain access. 
The British participants demonstrated a more focused approach to networking and an imbalance in time devoted for network contacts. The most frequently engaged contacts were relatives and key stakeholders. The British female entrepreneur expects to get moral support predominantly from the other females in her immediate environment. Interestingly, she does not have contact with universities although she thinks they might be a good source of skills improvement. The government and women-related organisations are the two contacts with whom she rarely engages. This can be interpreted as her reluctance to comply with more institutional forces through extended contacts. Similar to her British counterpart, the Turkish female entrepreneur also keeps her relatives closest to her and seeks moral support from family and/or friends, previous work colleagues, other women entrepreneurs and women-related organisations. However, she participates in women entrepreneurship-related government projects to get moral support too, this not being an overly common way of obtaining such support. Seemingly, she devotes more time for her network contacts than her British counterpart. The two main networking motivations reported are obtaining moral support and industry information. Differing from the British respondents, the Turkish female entrepreneur maintains a relationship with universities on an occasional basis to improve skills and commercial awareness.

To develop a better understanding of the facilitators of business survival, the Chi Square $\left(\chi_{2}\right)$ test was run (Table 6). Business survival was found to be strongly and significantly linked to sole ownership in the UK and to partnership with relatives in Turkey. The differentiated results indicate that the business survival and partnership status relationship in the case countries is strongly linked to the level of individualism present within their respective cultures.

Business survival was also significantly related to the entrepreneurs' age at startup. The Turkish female entrepreneur's first successful business startup experience is around 10 years later than her British female counterpart. This correlates to the period when the Turkish woman's children are older and less dependent, and resultantly her domestic responsibilities are reduced. From the institutional perspective, this serves as a primary condition to get her entrepreneurial attempts legitimised and accepted by society. Yet, the British female entrepreneur founds her first successful business before she gets married at the average age of 35 , with or without children. The entrepreneur's age factor, as explained above, is strongly linked to the power distance culture dimension. There are strict norms surrounding Turkish women's roles in society and appropriate ages to study, marry and have children throughout their life-cycle.

Both groups had preferred to establish a business in the service sector, which is generally characterised more as a female industry (Sweida and Alan, 2015). The participants' tendency to operate in a female industry can be explained through the cognitive institution perspective. Cognitive legitimisation refers to the spread of knowledge about a new venture. Correspondingly, Hannan and Freeman (1986: 63) noted that when an activity becomes so familiar and well known, attempts at creating copies of legitimated forms are common, and the success rate of such attempts is high (Aldrich and Fiol, 1994). And yet, the higher rate of manufacturing businesses among the Turkish participants can be interpreted with the maledomination of female businesses.

The findings show that the cultural characteristics of a society do have an impact on the successful business strategies of female entrepreneurs. This paper has examined the successful strategies employed by established British and Turkish female entrepreneurs in order to assess whether any difference in these strategies may potentially be attributed to cultural characteristics. The most remarkable impact on female businesses is observed within the collectivism-related cultural dimension evident in business partnership status and workload. 
The lower educational achievement of the Turkish participants is explained through the high power distance culture where the average age at first marriage for women is 23.3 years, their education subsequently coming to a halt. Power distance is also linked to business startup age and the networking behaviour of the established female entrepreneur. Evidently, as compared to her British counterpart, Turkish female entrepreneurs are older at startup and exhibit a more intense and interactive networking behaviour. This intensity partly stems from the institutional voids and lack of structures and support for female entrepreneurs which are filled by informal arrangements, such as close social ties with relatives and friends.

The individualism-collectivism dimension is linked to business partnership status, workload, growth orientation and perceived impediments towards business growth. Evidently, the British female entrepreneur prefers to act solo in business as opposed to her Turkish counterpart, who prefers partnership with relatives. Individual autonomy is more important than being a member of social groups and small organisations are favoured in individualistic cultures (OECD, 2016), while larger organisations are more desirable in the collectivist orientation (Abzari and Safari, 2014). That said, the British female entrepreneur does not want to grow her business for the sake of maintaining her work-life balance, but spends more time at work than her Turkish counterpart. The Turkish female entrepreneur does not want to grow so as to maintain control over the business. This study asserts that the cultural dimensions of power distance and collectivism/individualism have the most significant impact upon successful female entrepreneurial behaviour.

In this study, the institutional theory serves as a robust foundation to develop further discussions about the impact of culture on the the entrepreneurial behaviours and business survival strategies of female entrepreneurs within the given country contexts. Bruton et al.(2010) advocates that if institutions matter, then institutional theory should be employed as part of the analytical framework or may only serve to provide a background story for the research.

\section{Implications}

A number of implications emerge from this study. First, understanding the institutional context and the ways of gaining legitimacy as entrepreneurs within different countries (Turkey and the UK in this case) help females develop feasible market entry and survival strategies towards internationalisation; an almost inevitable step to ensure survival in the realm of the globalised economies and markets of today. Female entrepreneurs should therefore be aware of the cultural differences that exist among countries and their influence in shaping what constitutes a successful business strategy within these varying contexts.

Second, as an industry grows, increasing numbers of organisations raise its legitimacy along cognitive and sociocultural dimensions (Ranger-Moore et al. 1991; Aldrich and Fiol 1994). This study provides insights into the successful business survival strategies of females within two fundamentally different cultural patterns which will enable policy makers and women support organisations to work on developing ways for benchmarking to enhance success among female entrepreneurs.

Third, this study asserts that Turkish female entrepreneurs turn back to their families to overcome the cultural barriers towards entrepreneurial success in the absence of suitable external support mechanisms which might create conflict and exacerbate women entrepreneurs' problems due to family members' authority. This study emphasises the importance of receiving suitable support from accessible women support organisations evident in the female entrepreneurs' networking preferences in this study. On the UK side, women 
support organisations is of a fundamental importance of empowering female entrepreneurs especially when considering the majority is acting solo in business.

Forth, this study posits that policy makers should take into account the invisible internal family dynamics and the importance of operationalising family and households for women's businesses' survival (Carter and Ram 2003; Aldrich and Cliff 2003) especially within the Turkey context.

\section{Limitations}

This study uses Hofstede's findings to describe the cultural environments within the selected regions in Turkey and in the UK. This model is one of the most representatives in analysing cultural values although its methodology is criticisable mainly due to the generalization of group results at a national level (Brancu et al. 2015). Also, a culture is a multilayered phenomenon might posses different characteristics at national and regional level and individuals may have different degrees of the cultural values captured in Hofstede's dimensions.

This study does not focus on broader institutional factors influencing entrepreneurship but examines the impact of the culture, solely derived from Hofstede's (2001) dimensions, on the business survival strategies of females.

Hofstede et al. (2004) suggest that misfit individuals attempt to start ventures because they do not share the dominant cultural values. This study seems have excluded "misfits" from the scope. 


\section{Bibliography}

Achtenhagen, L. \& Welter, F., 2007. Media Discourse in Entrepreneurship Research. In: J. P. U. elle Neergaard, ed. Qualitative Methods in Entrepreneurship Research. s.l.:Elgar, pp. 193-215.

Ahlstrom, D. \& Bruton, G., 2002. An Institutional Perspective on the Role of Culture in Shaping Strategic Actions by Technology-Focused Entrepreneurial Firms in China. Entrepreneurship Theory and Practice, 26(4), pp. 53-68.

Aldrich , H. \& Fiol, M., 1994. Fools rush in? The institutional context of industry creation. Academy of Management Review, Volume 19, pp. 645-670.

Allen, E., Brush, C., Bruin, A. d. \& Welter, F., 2010. Gender Embeddedness of Women Entrepreneurs: An Empirical Test of the "5M" Framework. Massachusetts, Babson College Entrepreneurship Research Conference.

Bates, T., Jackson, W. E. \& Johnson, J. H., 2007. Introduction: Advancing Research on Minority Entrepreneurship. The Annals of the American Academy of Political and Social Science, Volume 613, pp. 10-17.

Baughn, C. C., Chua, B.-L. \& Neupert, K. E., 2006. The Normative Context for Women's Participation in Entrepreneruship: A Multicountry Study. ENTREPRENEURSHIP THEORY and PRACTICE, 30(5), pp. 687-708.

Baumol, W., Schramm, C. \& Litan, R., 2007. Good Capitalism, Bad Capitalism, and the Economics of Growth and. s.l.:Yale University.

Bonchek, M. \& Shepsle, K., 1996. Analyzingpolitics:Rationality, behaviorandinstititutions. New York: Nortoc \& Co..

Brancu, L., Guðmundsdóttir, S., Gligor, D. \& Munteanu, V., 2015. Is culture a moderator of entrepreneurship motivation? A comperative study of Romania and IcelandND. Amfiteatru Economic, 17(38), pp. 133-147.

Brush, C. G., de Bruin, A. \& Welter, F., 2009. A gender-aware framework for women's entrepreneurship. International Journal of Gender and Entrepreneurship, 1(1), pp. 8-24.

Bruton, G. \& Ahlstrom, D., 2003. An Institutional View of China's Venture Capital Industry: Explaining the Differences between China and the West. Journal of Business Venturing, 18(2), pp. 233-259.

Bruton, G. D., Ahlstrom, D. \& Li, H.-L., 2010. Institutional Theory and Entrepreneurship: Where Are We Now and Where Do We Need to Move in the Future?. Entrepreneurship Theory and Practice, 34(3), pp. 421-440.

Busenitz, L. W., Gomez, C. \& Spencer, J. W., 2000. Country Institutional Profiles: Unlocking Entrepreneurial Phenomena. Academy of Management, 43(5), pp. 994-1003.

Carter, S., Mason, C. \& Tagg Stephen, 2006. Lifting the Barriers to Growth in UK Small Businesses The FSB Biennial Membership Survey. Glasgow: National Federation of Self Employed \& Small Businesses.

Country Economy, 2018. Demography. [Online]

Available at: https://countryeconomy.com/demography/literacy-rate/turkey

[Accessed 2401 2019]. 
Dad, 2019. Paternity leave in the UK. [Online]

Available at: https://www.dad.info/article/paternity-leave-in-the-uk

[Accessed 2901 2019].

Davidsson, P., 1995. Small firms, business dynamics and differential development of economic wellbeing. Small Business Economics, 7(4), pp. 301-315.

Deloitte, 2016. Women entrepreneurs: Developing Collaborative Ecosystmes for Success, s.1.:

Deloitte.

Esping-Andersen, G., 2010. The Incomplete Revolution: Adapting to Women's New Roles. Journal of Social Policy, 39(3), pp. 483-503.

Etzioni, A., 1987. Entrepreneurship, adaptation and legitimation: A macro-behavioral perspective.

Journal of Economic Behavior \& Organization, 8(2), pp. 175-189.

Fernandes, P., 2018. 7 Challenges Women Entrepreneurs Face. [Online]

Available at: https://www.businessnewsdaily.com/5268-women-entrepreneur-challenges.html [Accessed 0101 2018].

Fowler, F., 2009. Survey Research Methods. s.1.:s.n.

Freytag, A. \& Thurik, R., 2007. Entrepreneurship and its determinants in a cross-country setting. Journal of Evolutionary Economics, 17(2), pp. 117-131.

GEM, 2017. UK Report, s.l.: Babson.

Glasow, P. A., 2005. Fundamentals of Survey Research Methodology. [Online]

Available at: https://www.mitre.org/sites/default/files/pdf/05_0638.pdf

[Accessed 2301 2019].

GOV, 2018. Participation rates in higher education: 2006 to 2017. [Online]

Available at: https://www.gov.uk/government/statistics/participation-rates-in-higher-education-2006to- 2017

[Accessed 2401 2019].

Hatun, U. \& Ozgen, O., 2001. Interaction between the business and family lives of women entrepreneurs in Turkey. Journal of Business Ethics, Volume 31, pp. 95-106.

Hayton, J. C. \& Cacciotti, G., 2013. Is there an entrepreneurial culture? A review of empirical research. Entrepreneurship \& Regional Development, 25(9-10), pp. 708-731.

Hayton, J. C., George, G. \& Zahra, S. A., 2002. National Culture and Entrepreneurship : A Review of Behavioral Research. Entrepreneurship Theory and Practice, 26(4), pp. 33-52.

Hisrich, R. \& Brush, C., 1988. Women entrepreneurs: Problems and opportunities. In: Women's careers, pathways and pitfalls. New York: Greenwood Press., pp. 193-207.

Hisrich, R. \& Ozturk, S. A., 1999. Women entrepreneurs in a developing economy. Journal of Management, Volume 18, pp. 114-124.

Hofstede, 2018. National Culture. [Online]

Available at: https://www.hofstede-insights.com/models/national-culture/

[Accessed 2606 2018].

Huffingtonpost, 2014. Business Partnerships With Men Often Don't Benefit Women, According To

Study. [Online]

Available at: https://www.huffingtonpost.com/2014/04/09/business-partnerships-women- 
study_n_5117809.html?guccounter=1

[Accessed 0102 2019].

ILO, 2018. Informal Economy. [Online]

Available at: https://www.ilo.org/global/about-the-ilo/newsroom/news/WCMS_627189/lang-en/index.htm

[Accessed 0101 2019].

Itani, H., Sidani, Y. M. \& Baalbaki, I., 2011. United Arab Emirates female entrepreneurs: motivations and frustrations. Equality, Diversity and Inclusion: An International Journal, 30(5), pp. 409-424.

Jack, S. \& Anderson, A. R., 2002. The Effects of Embeddedness on the Entrepreneurial Process. Journal of Business Venturing, 17(5), pp. 467-487.

Jayawarna, D., Rouse, J. \& Crompton, H., 2006. The NES Follow-up Survey 2006. [Online]

Available at: https://e-space.mmu.ac.uk/83891/1/NESfollowup.pdf

[Accessed 0402 2016].

Kaciak, E. \& Welsh, D., 2018. Women's entrepreneurship: A model of business-family interface and performance. The International Entrepreneurship and Management Journal, Volume 14, pp. 627-637.

Krueger, N., Linan, F. \& Nabi, G., 2013. Cultural values and entrepreneurship. Entrepreneurship \& Regional Development, 25(9-10), pp. 703-707.

Krueger, N., Reilly, M. \& Carsrud, A., 2000. Competing models of entrepreneurial intentions. Journal of Business Venturing, 15(5-6), pp. 411-432.

Kutanis, R. O. \& Bayraktaroglu, S., 2003. Female entrepreneurs: Social feminist insights for overcoming the barriers. [Online]

Available at:

https://www.mngt.waikato.ac.nz/ejrot/cmsconference/2003/proceedings/gender/Kutanis.pdf [Accessed 0201 2019].

Lee-Gosselin, H. \& Grise, J., 1990. Are women owner-managers challenging our definitions of entrepreneurship?. Journal of Business Ethics, Volume 9, pp. 423-433.

Marlow, S., 2002. Women and Self-Employment: A Part of or Apart from Theoretical Construct?. The International Journal of Entrepreneurship and Innovation, 3(2), pp. 83-91.

McGuinness, F., 2018. Women and the Economy Briefing Paper, London: House of Commons.

Meyer, J. \& Rowan, B., 1977. Institutionalized Organizations: Formal Structure as Myth and Ceremony. American Journal of Sociology, 83(2), pp. 340-363.

Moghadam, V. M., 2003. Modernizing Women: Gender and Social Change in the Middle East. Second ed. Colorado: Lyenne Rienner.

Mueller, S. L. \& Thomas, A. S., 2001. Culture and entrepreneurial potential: A nine country study of locus of control and innovativeness. Journal of Business Venturing, 16(1), pp. 51-75.

Nazliaka, A., 2017. Advancing Women's Equality in Turkey. Turkish Policy Quarterly, 16(2), pp. 4956.

North, D., 1990. Institutions, institutional change and economic performance. New York: Cambridge University Press.

OECD, 2016. Policy Brief on Women's Entrepreneurship, Luxembourg: OECD. 
OECD, 2018. Gender differences in self-employment rates. [Online]

Available at: https://www.oecd-ilibrary.org/docserver/entrepreneur_aag-2017-

en.pdf?expires $=1548160191 \& i d=i d \&$ accname $=$ guest $\&$ checksum $=8 \mathrm{E} 92 \mathrm{~A} 51 \mathrm{C} 3 \mathrm{~F} 20664 \mathrm{AD} 4 \mathrm{BFB} 48 \mathrm{DF}$

2F44FBB

[Accessed 2201 2019].

OECD, 2018. Indicators of entrepreneurial determinants. [Online]

Available at: http://www.oecd.org/sdd/business-stats/indicatorsofentrepreneurialdeterminants.htm [Accessed 2901 2019].

Osoba, B. J., 2009. Culture and entrepreneurial activity in the United States: a quantitative analysis. The European Journal of Social Science Research , 22(3), pp. 341-370.

Phillips, M., Attar Taylor, E. \& Dange, P., 2013. British Social Attitudes, London: NatCen Social Research.

Powell, W. \& Dimaggio, P., 1991. The New Institutionalism in Organizational Analysis. s.l.:The University of Chicago.

Scott, J. \& Clery , E., 2013. Gender roles: An incomplete revolution? , London: NatCen Social Research.

Scott, R., 2007. Institutions and organizations: Ideas and interests. CA: Sage.

Shelton, L., 2006. Female entrepreneurs, work-family conflict, and venture performance: New insights into the work-family interface. Journal of Small Business Management, 44(2), pp. 285-297.

Simsek, M. \& Uzay, N., 2009. Economic and social problems of women entrepreneurs and Turkey application. Journal of Academic Research in Economics, Volume 1, p. 289-307.

Srivastava, S., 2017. Exploring antecedents of entrepreneurial intentions of young women in India: A multi-method analysis. Journal of Entrepreneurship in Emerging Economies, 9(2), pp. 181-206.

Stephan, U. \& Uhlaner, L. M., 2010. Performance-Based vs. Socially Supportive Culture: A CrossNational Study of Descriptive Norms and Entrepreneurship. Journal of International Business Studies, Volume 41, pp. 1347-1364.

Steyaert, C., 2007. 'Entrepreneuring' as a conceptual attractor? A review of process theories in 20 years of entrepreneurship studies. Entrepreneurship \& Regional Development, 19(6), pp. 453-477.

Stinchcombe, A. L., 2000. Social Structure and Organizations. Advances in Strategic Management, Volume 17, pp. 229-259.

Suchman, M. C., 1995. Managing Legitimacy: Strategic and Institutional Approaches. The Academy of Management Review, 20(3), pp. 571-610.

Sweida, G. \& Alan, J. W., 2015. Comparing The Development of Entrepreneurial Self-Efficacy of Female Entrepreneurs in Male- and Female-Dominated Industries. Journal of Developmental Entrepreneurship, 20(3), pp. 1-20.

Terjesen, S. \& Lloyd, A., 2015. The Female Entrepreneurship Index (FEI) , Washington, D.C.: Global Entrepreneurship and Development Institute .

The World Bank, 2018. Labor force participation rates. [Online] Available at: https://data.worldbank.org/indicator/SL.TLE.CACT.MA.NE.ZS?view=map [Accessed 2501 2019].

Theurl, T. \& Wicher, J., 2012. Comparing Imformal Institutions, s.l.: DICE Reports. 
Thornton, P. H., Ribeiro-Soriano, D. \& Urbano, D., 2011. Socio-cultural factors and entrepreneurial activity: An overview. International Small Business Journal, 29(2), pp. 105-118.

Thurik, R. \& Dejardin, M., 2012. Entrepreneurship and Culture. Entrepreneurship in Context, pp. 175-186.

Tukur, N. M. \& Adam, S. I., 2017. Culture and Entrepreneurship: An Overview of Hofstede's Cultural Dimensions. Journal of Economics and Finance, 2(7), pp. 17-21.

Turkstat, 2018. Labour Force Statistics. [Online]

Available at: http://www.turkstat.gov.tr/PreTablo.do?alt_id=1007

[Accessed 2401 2019].

Ute, S. \& Uhlaner, L., 2010. Performance-based vs socially supportive culture: a cross-national study of descriptive norms and entrepreneurship. Journal of International Business Studies, 41(8), pp. 13471364.

Welsh, D., Memili, E. \& Kaciak, E., 2016. An Empirical Analysis of The Impact of Family Support on Turkish Women Entrepreneurs. Journal of Innovation and Knowledge, 1(1), pp. 3-12.

Wennberg, K., Pathak, S. \& Autio, E., 2013. How culture moulds the effects of self-efficacy and fear of failure on entrepreneurship. Entrepreneurship \& Regional Development, 25(9-10), pp. 756-780.

Williams, F., 2005. Rethinking Families. s.l.:Calouste Gulbenkian Foundation.

Yetim, N., 2008. Social Capital in Female Entrepreneurship. International Sociology, 23(6), pp. 864885 . 